\title{
24. THE AGE OF TERRIGENOUS MINERALS OF THE BLACK SEA SEDIMENTS
}

\author{
A. Ya. Krylov, V. G. Khlopin Radium Institute,Leningrad, USSR \\ and \\ E.S. Trimonis, Atlantic Division, P.P. Shirshov Institute of Oceanology, Kaliningrad, USSR
}

\section{INTRODUCTION}

The method for absolute dating of terrigenous minerals in marine sediments suggested and developed in the USSR (Krylov and Silin, 1959, 1963; Krylov et al., 1961) is used now successfully for the study of terrigenous sedimentation in sea basins. Comparison of these data with the age of the minerals in the rocks of the drainage areas can define the source of the sedimentary material delivered into different parts of the basin. This method was also used in the study of Recent and late Quaternary sedimentation in the Black Sea (Krylov, Avdzeiko et al., 1973; Krylov, Emelyanov, et al., 1973). Besides serving as an age mark and indicator of source areas of the terrigenous matter, it also proved valuable for solving problems of the paleogeography of the Recent basins (Krylov and Silin, 1963; Krylov, Emelyanov, et al., 1973). A similar method was used for similar purposes in examination of the drilling cores obtained during Leg $42 \mathrm{~B}$ in the Black Sea.

\section{PREVIOUS RESEARCH}

Knowledge about the age of sedimentary minerals mobilized in the Black Sea drainage area can be obtained from an analysis of river alluvium and beach sands which extend from the Danube River mouth to Batumi (Krylov, Avdzeiko, et al., 1973). The Danube River is a source of sedimentary material for Recent sediments, and contains terrigenous minerals with an age of 200 to 225 m.y. The oldest mineral load is derived from the rivers draining the Russian Platform rocks-the Southern Bug (1080-1260 m.y.) and the Dnieper (1165 m.y.). Beach sands of the Crimean coast are composed mainly of minerals whose age ranges from 185 to $340 \mathrm{~m}$.y. Rivers of the Caucasus northwestern slope deliver terrigenous minerals 195 to $570 \mathrm{~m}$.y. old, but their contribution to Recent basins is insignificant. The most powerful Caucasian rivers (Bzyb, Inguri, Rioni, etc.) transport minerals of younger age: 140-185 m.y. The minimal age of terrigenous minerals was identified for the river Chorokh -40 to 70 million years. In the early stages of the Black Sea Quaternary history, considerable sedimentary matter may have been supplied by the Don and Kuban. The age of terrigenous minerals in these river loads accordingly is 400 to $650 \mathrm{~m}$.y. and 230 to $320 \mathrm{~m}$.y. These data are schematically represented in Figure 1.

Studies of the age of the Black Sea upper Quaternary sediments show that the age of terrigenous minerals in the deep-sea muds in the upper Würm Holocene varies insignificantly, from 150 to $230 \mathrm{~m}$.y. (Krylov, Avdzeiko, et al., 1973; Krylov, Emelyanov, et al., 1973). Sharp differences

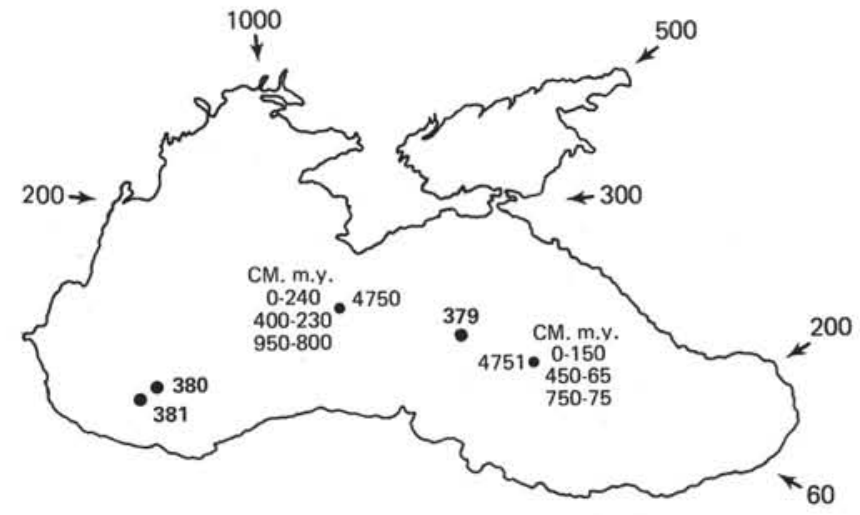

Figure 1. Age of terrigenous minerals in the river suspensions and Black Sea sediments. Arrows show the age of terrigenous minerals in the river suspensions (m. y.) in the columns: left-depth of cores in $\mathrm{cm}$; right-age of terrigenous minerals (m. y.).

occur only for the interbeds of coarse-grained matter (silts and sands) extending into Würm deposits synchronous with melting of glaciers. In the eastern Black Sea sediments, terrigenous minerals are 65 to $75 \mathrm{~m} . \mathrm{y}$. old (Table 1), which indicates that formation of these interbeds is due to the Eastern Pontic river loads; in the central part, sandy-silt interbeds of terrigenous minerals (600 to 800 m.y.B.P.) may be linked to loads from the Russian Platform.

\section{METHODS}

The basic principles of potassium-argon dating of terrigenous minerals are described in early articles (Krylov and Silin, 1959, 1963; Krylov et al., 1961). The same methods were used in this study. Samples of sediments were treated with nitric acid for removal of carbonates and adsorbed potassium. Potassium was determined by dipicrilaminatic and flame-photometric methods; argon was determined by isotopic dilution, using a type MC-2M mass-spectrometer.

\section{RESULTS}

Data concerning the ages of terrigenous minerals from sites studied are given in Table 2 and shown in Figure 2.

The deposits of Hole 379A were formed during different epochs of sedimentation, both during the glacial periods, when sea level was lower than at present and the climate throughout the drainage area was cold and dry, and during the interglacial periods which were characterized by a rapid rise 
TABLE 1

Absolute Age of Terrigenous Minerals in the Black Sea Bottom Sediments

\begin{tabular}{|c|c|c|c|c|c|c|c|c|c|}
\hline \multirow[b]{2}{*}{ Station } & \multirow{2}{*}{$\begin{array}{c}\text { Depth } \\
\text { (m) }\end{array}$} & \multicolumn{2}{|c|}{ Coordinates } & \multirow{2}{*}{$\begin{array}{c}\text { Interval } \\
(\mathrm{cm})\end{array}$} & \multirow{2}{*}{$\begin{array}{l}\text { Strati- } \\
\text { graphic } \\
\text { Layer }\end{array}$} & \multirow[b]{2}{*}{ Type of Sediment } & \multirow{2}{*}{$\begin{array}{c}\mathrm{K} \\
(\%)\end{array}$} & \multirow{2}{*}{$\mathrm{Ar} \frac{\mathrm{cm}^{3}}{\mathrm{~g}} \cdot 10^{-5}$} & \multirow{2}{*}{$\begin{array}{l}\text { Age, } \\
\text { (m.y.) }\end{array}$} \\
\hline & & N.L. & E.L. & & & & & & \\
\hline \multirow[t]{3}{*}{4750} & 2163 & $42^{\circ} 30^{\prime} 9^{\prime \prime}$ & $37^{\circ} 34^{\prime} 3^{\prime \prime}$ & $0-37$ & $\mathrm{Hl}_{\mathrm{III}}$ & Pelitic mud & 2.08 & 1.20 & 150 \\
\hline & & & & $435-493$ & $\mathrm{w}^{\mathrm{m}}$ & Fine-grained sand & 1.62 & 0.39 & 65 \\
\hline & & & & $720-760$ & W & Medium-grained sand & 1.65 & 0.49 & 75 \\
\hline \multirow[t]{4}{*}{4751} & 2222 & $43^{\circ} 12^{\prime} 4^{\prime \prime}$ & $33^{\circ} 48^{\prime}$ & $0-25$ & $\mathrm{Hl}_{\mathrm{III}}$ & Pelitic mud & 2.39 & 2.30 & 240 \\
\hline & & & & $59-115$ & $\mathrm{Hl}_{\mathrm{III}}$ & Aleurite-pelitic ooze & 1.94 & 0.95 & 125 \\
\hline & & & & $390-435$ & W & Pelitic mud & 2.38 & 2.22 & 230 \\
\hline & & & & $946-966$ & W & Sand & 0.82 & 3.10 & 800 \\
\hline \multirow[t]{2}{*}{4752} & 2214 & $43^{\circ} 32^{\prime} 9^{\prime \prime}$ & $33^{\circ} 54^{\prime} 3^{\prime \prime}$ & $0-25$ & $\mathrm{Hl}_{\mathrm{III}}$ & Pelitic ooze & 2.40 & 1.76 & 180 \\
\hline & & & & $770-790$ & $\mathrm{~W}^{*}$ & Coarse aleurite & 1.69 & 0.56 & 85 \\
\hline \multirow[t]{3}{*}{4754} & 1330 & $41^{\circ} 36^{\prime} 1^{\prime \prime}$ & $29^{\circ} 23^{\prime} 7^{\prime \prime}$ & $0-15$ & $\mathrm{Hl}_{\mathrm{III}}$ & Pelitic mud & 2.51 & 1.66 & 170 \\
\hline & & & & $170-185$ & $\mathrm{HI}_{\mathrm{III}}$ & Pelitic mud & 2.36 & 1.42 & 150 \\
\hline & & & & $611-624$ & $w^{111}$ & Pelitic mud & 3.44 & 2.16 & 155 \\
\hline \multirow[t]{2}{*}{672} & 2215 & $42^{\circ} 31^{\prime} 3^{\prime \prime}$ & $31^{\circ} 56^{\prime} 2^{\prime \prime}$ & $0-29$ & $\mathrm{Hl}_{\mathrm{III}}$ & Pelitic mud & 1.90 & 1.24 & 165 \\
\hline & & & & $235-250$ & $w^{m}$ & Coarse aleurite & 1.65 & 5.15 & 600 \\
\hline
\end{tabular}

Note: Designation of Stratigraphic Layer: $\mathrm{Hl}_{\mathrm{III}}=$ recent sediments $(\mathrm{u}$. Holocene); $\mathrm{Hl} I \mathrm{III}=$ old Black sea sediments $(\mathrm{m}$. Holocene); $\mathrm{W}=$ new euxinic sediments (Würm).

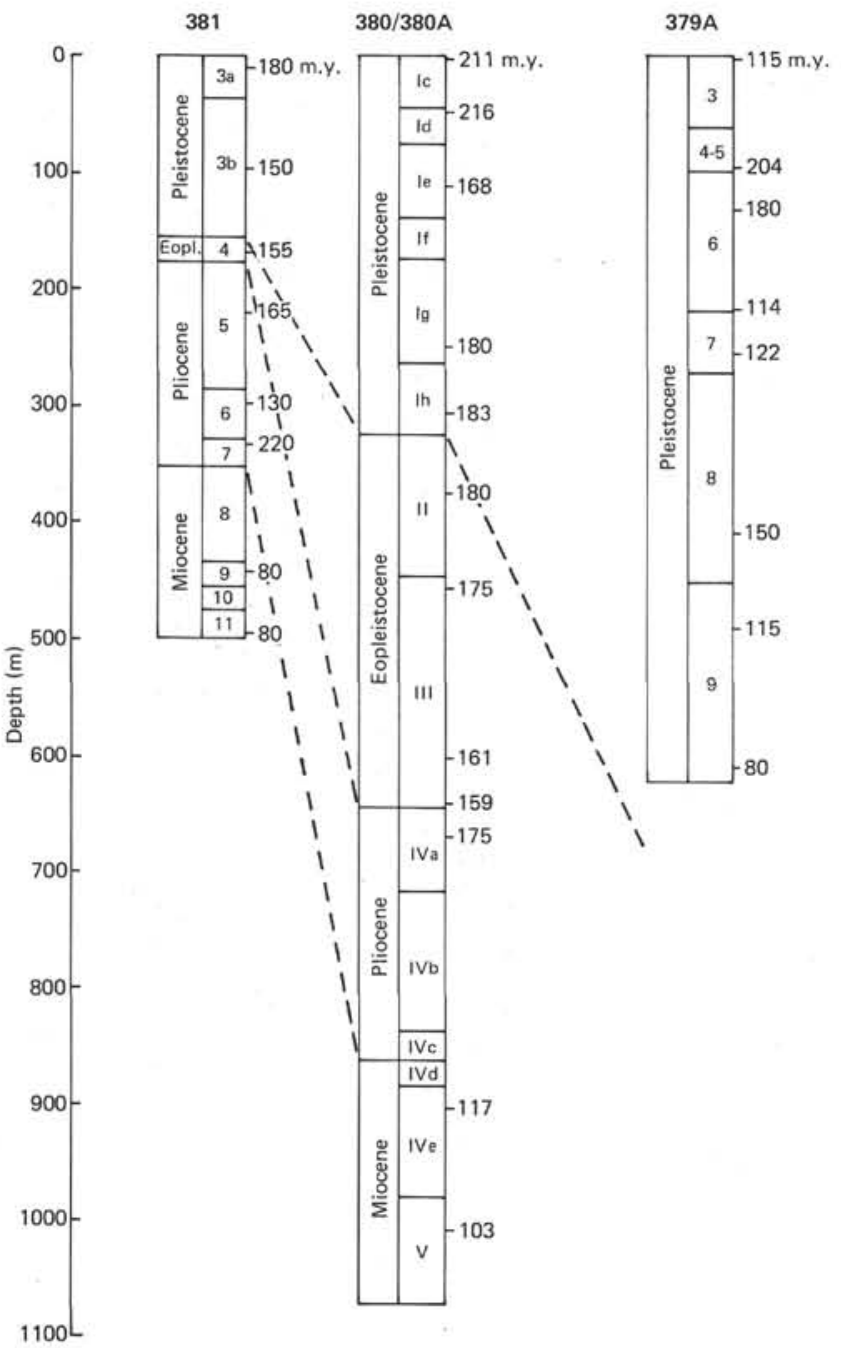

Figure 2. Age of terrigenous minerals (million years).

of water level and a more marine regime in the basin, with warm and wet climate over the drainage area. The principal part of the Pleistocene section consists of terrigenous deposits represented by aleuritic-pelitic and pelitic muds. The age of terrigenous minerals of these sediments in lithologic units of different ages shows small variations-from 204 to 114 m.y. The youngest ( 80 m.y.) occurs in Sample 379A$67-4,110-120 \mathrm{~cm}$ (lower Pleistocene), in the sandy silt of a sample whose major portion consists of finely dispersed terrigenous matter. The data obtained enable us to discuss only the sources of the finest suspension delivered from the drainage area.

The age of terrigenous material formed during three glacial epochs (Würm, Riss, Mindel) is 114 to $180 \mathrm{~m}$.y. almost the same age is noted for the terrigenous minerals in the finely dispersed deposits of the interglacial periods (115 to 204 m.y.). This indicates that during the Pleistocene there were no cardinal changes in supply sources for the sedimentation area. Additionally, this is supported by the mineral composition of sediments, which shows similar ratios of basic rockforming minerals (Table 3 ).

The mineralogy study of the coarse-silt fraction (0.1-0.05 $\mathrm{mm}$ ) shows that the terrigenous matter from this site is of mixed genesis. Moreover, it is characteristic of the southern drainage system loads at individual stages of units (or some parts of them); the material was delivered largely from the Caucasus (Trimonis and Shimkus, this volume). The sediments of the Riss glacial period (Unit 6) may be given as an example. In the coarse-silt fraction of terrigenous muds, the mineral composition changes repeatedly. This is expressed by considerable variations in the contents of monoclinic pyroxenes, epidote, opaque minerals, etc. There are large amounts of garnet in a number of beds. Zircon, tourmaline, and kyanite are often present; this is not characteristic of the southern drainage system loads. The ages of terrigenous minerals in two samples are 114 and $180 \mathrm{~m} . \mathrm{y}$. The age increase is probably connected with a larger admixture of sedimentary material transported from the northern source areas. The marked variation in the ages of the terrigenous minerals in other units also indicates the increasing role of sedimentary matter from the Caucasus drainage areas in the sedimentation at some stages of the Pleistocene. 
TABLE 2

Absolute Ages of Terrigenous Minerals

\begin{tabular}{|c|c|c|c|c|c|c|c|}
\hline $\begin{array}{l}\text { Sample } \\
\text { (Interval } \\
\text { in } \mathrm{cm} \text { ) }\end{array}$ & Depth (m) & Unit & Age & Type of Sediment & $\mathrm{K}(\%)$ & $\operatorname{Ar}\left(\frac{\mathrm{cm}^{3}}{\mathrm{~g}} \cdot 10^{-5}\right)$ & Age (m.y.) \\
\hline \multicolumn{8}{|l|}{ Hole 379A } \\
\hline $1-4,115-125$ & $5.65-5.75$ & 3 & Würm & Terrigenous mud & 2.06 & 0.932 & $115 \pm 5$ \\
\hline $11-4,135-143$ & $98.35-98.43$ & 4 & $\begin{array}{l}\text { Riss- } \\
\text { Würm }\end{array}$ & Terrigenous mud & 2.06 & 1.680 & $204 \pm 10$ \\
\hline $15-3,45-58$ & $133.95-134.08$ & 6 & Riss & Terrigenous mud & 2.12 & 1.570 & $180 \pm 9$ \\
\hline $24-2,0-18$ & $217.50-217.68$ & 6 & Riss & Terrigenous mud & 1.85 & 0.826 & $114 \pm 5$ \\
\hline $28-2,82-93$ & $256.32-256.43$ & 7 & $\begin{array}{l}\text { Mindel- } \\
\text { Riss }\end{array}$ & Terrigenous mud & 1.87 & 0.887 & $122 \pm 6$ \\
\hline $45-4,98-106$ & $411.48-411.56$ & 8 & Mindel & Terrigenous mud & 2.05 & 1.219 & $150 \pm 7$ \\
\hline $54-2,20-34$ & $493.20-493.34$ & 9 & $\begin{array}{l}\text { Gunz- } \\
\text { Mindel }\end{array}$ & Calcite-rich mud & 1.83 & 0.826 & $115 \pm 5$ \\
\hline $67-4,110-120$ & $611.10-611.20$ & 9 & $\begin{array}{l}\text { Gunz- } \\
\text { Mindel }\end{array}$ & Terrigenous sandy silt & 1.77 & 0.548 & $80 \pm 4$ \\
\hline \multicolumn{8}{|l|}{ Hole 380} \\
\hline $1-3,10-20$ & $3.10-3.20$ & $1 \mathrm{c}$ & Würm & Terrigenous mud & 2.58 & 2.182 & $211 \pm 11$ \\
\hline $6-1,93-105$ & $48.43-48.55$ & $1 \mathrm{~d}$ & $\begin{array}{l}\text { Riss- } \\
\text { Würm }\end{array}$ & $\begin{array}{l}\text { Terrigenous diatom- } \\
\text { rich silty mud }\end{array}$ & 2.34 & 2.029 & $216 \pm 11$ \\
\hline $13-1,0-14$ & $114.00-114.14$ & $1 \mathrm{e}$ & Riss & Terrigenous mud & 2.85 & 1.900 & $168 \pm 8$ \\
\hline $27-3,1-13$ & $250.01-250.13$ & $1 \mathrm{~g}$ & Mindel & Terrigenous mud & 2.64 & 1.893 & $180 \pm 9$ \\
\hline $33-3,95-110$ & $307.95-308.10$ & $1 \mathrm{~h}$ & Mindel & Terrigenous silty mud & 2.35 & 1.720 & $183 \pm 9$ \\
\hline \multicolumn{8}{|l|}{ Hole $380 \mathrm{~A}$} \\
\hline $5-4,61-74$ & $375.61-375.74$ & II & $\begin{array}{l}\text { Eoplei- } \\
\text { stocene }\end{array}$ & Terrigenous mud & 3.20 & 2.290 & $180 \pm 9$ \\
\hline $14-2,62-77$ & $458.12-458.27$ & III & $\begin{array}{l}\text { Eoplei- } \\
\text { stocene }\end{array}$ & Terrigenous mud & 2.60 & 1.804 & $175 \pm 9$ \\
\hline $30-2,38-50$ & $600.38-600.50$ & III & $\begin{array}{l}\text { Eoplei- } \\
\text { stocene }\end{array}$ & Calcareous mud & 2.48 & 1.650 & $161 \pm 8$ \\
\hline $34-3,27-44$ & $629.77-639.94$ & III & $\begin{array}{l}\text { Eoplei- } \\
\text { stocene }\end{array}$ & Marly calcareous mud & 2.43 & 1.557 & $159 \pm 8$ \\
\hline $37-4,1-14$ & $669.51-669.64$ & IVa & Pliocene & Terrigenous mud & 1.89 & 1.357 & $175 \pm 9$ \\
\hline $48-6,41-53$ & $776.91-777.03$ & $\mathrm{IVb}$ & Pliocene & Terrigenous mud & 2.09 & & \\
\hline $62-2,0-15$ & $904.00-904.15$ & IVe & Miocene & Marly calcareous silt & 2.54 & 1.005 & $117 \pm 6$ \\
\hline $73-3,16-27$ & $1010.16-1010.27$ & V & Miocene & Terrigenous silt & 2.50 & 1.030 & $103 \pm 5$ \\
\hline \multicolumn{8}{|l|}{ Site 381} \\
\hline $2-2,124-144$ & $12.24-12.44$ & $3 a$ & $\begin{array}{l}\text { Mindel- } \\
\text { Riss }\end{array}$ & Terrigenous mud & 2.53 & 1.805 & $180 \pm 9$ \\
\hline $5-3,115-135$ & $42.15-42.35$ & $3 b$ & Mindel & Terrigenous mud & 2.60 & & \\
\hline $11-2,0-15$ & $96.50-96.65$ & $3 \mathrm{~b}$ & Mindel & Terrigenous mud & 2.56 & 1.540 & $150 \pm 7$ \\
\hline $19-1,0-15$ & $171.00-171.15$ & 4 & $\begin{array}{l}\text { Eoplei- } \\
\text { stocene }\end{array}$ & Carbonate silty mud & 1.61 & 0.974 & $155 \pm 8$ \\
\hline $25-2,40-55$ & $220.40-220.55$ & 5 & Pliocene & Terrigenous mud & 2.19 & 1.428 & $165 \pm 8$ \\
\hline $33-4,120-135$ & $300.20-300.35$ & 6 & Pliocene & Marly calcareous mud & 2.08 & 1.044 & $130 \pm 7$ \\
\hline $37-2,30-40$ & $334.30-334.40$ & 7 & Pliocene & Terrigenous silty mud & 2.00 & 1.764 & $220 \pm 11$ \\
\hline $48-6,110-120$ & $445.60-445.70$ & 9 & Miocene & Terrigenous silty mud & 2.51 & 0.793 & $80 \pm 4$ \\
\hline $54-2,5-16$ & $495.55-495.66$ & 11 & Miocene & Siltstone & 2.05 & 0.639 & $80 \pm 4$ \\
\hline
\end{tabular}

The coarse-grained material (Sample 367A-67-4, 110-120 $\mathrm{cm}$ ) is $80 \mathrm{~m} . \mathrm{y}$. old, indicating that sedimentary matter from the southern drainage area is predominant there. It contains a relatively small proportion of clay minerals (especially illite), and is enriched in feldspar (Table 3). Of all the heavy minerals in the coarse-silt fraction, the predominant ones are monoclinic pyroxenes, opaques, epidote, as well as weathered rock fragments; feldspars (to a greater extent than quartz) are in the light fraction. This composition is typical of the Recent eastern Anatolian terrigenous province, supplied mainly with products of the destruction of Cretaceous igneous rocks and Quaternary effusive formation in Turkey. It should be expected that the interbeds of coarse-grained matter in other units, which were not dated, are genetically associated with the sedimentary material, mobilized in the southern part of the drainage area.

Holes $380,380 \mathrm{~A}$, and 381 are closely spaced and their lithological units are of similar composition. Holes 380 and $380 \mathrm{~A}$ had better recovery and were drilled in Pleistocene to Miocene sediments. At Site 381 these deposits are thinner. The principal portion of the Pleistocene sediments at both sites is formed of terrigenous aleuritic-pelitic and pelitic muds. The Pliocene sediments are more enriched in carbonate matter, especially at Site 380; in the Miocene strata laminated clays prevail.

Most of the samples from Holes 380 and $380 \mathrm{~A}$ were studied because of their fine grain size of finely dispersed muds. The age of the terrigenous minerals for the Pleistocene 
TABLE 3

X-Ray Diffraction Results for the Bulk Samples

\begin{tabular}{|c|c|c|c|c|c|c|c|c|c|c|}
\hline \multirow{2}{*}{$\begin{array}{c}\text { Sample } \\
\text { (Interval } \\
\text { in } \mathrm{cm} \text { ) }\end{array}$} & \multicolumn{10}{|c|}{ Total Crystalline Components $=100 \%$} \\
\hline & Quartz & $\begin{array}{l}\text { Feld- } \\
\text { spars }\end{array}$ & Illite & $\begin{array}{l}\text { Montmoril- } \\
\text { lonite }\end{array}$ & Chlorite & $\begin{array}{c}\text { Kaolin- } \\
\text { ite }\end{array}$ & Calcite & $\begin{array}{c}\text { Other } \\
\text { Carbonates }\end{array}$ & Pyrite & $\begin{array}{c}\text { Other } \\
\text { Minerals }\end{array}$ \\
\hline \multicolumn{11}{|l|}{ Hole 379A } \\
\hline $\begin{array}{l}24-2,0-18 \\
28-2,82-93 \\
45-4,98-106 \\
54-2,20-34 \\
67-4,110-120\end{array}$ & $\begin{array}{r}13.5 \\
14.5 \\
15.0 \\
8.9 \\
19.3\end{array}$ & $\begin{array}{l}13.2 \\
11.1 \\
11.6 \\
11.6 \\
39.4\end{array}$ & $\begin{array}{r}24.2 \\
23.4 \\
19.6 \\
23.1 \\
8.0\end{array}$ & $\begin{array}{r}12.1 \\
7.4 \\
12.4 \\
4.7 \\
9.5\end{array}$ & $\begin{array}{r}22.2 \\
20.1 \\
15.2 \\
18.2 \\
8.9\end{array}$ & $\begin{array}{l}\text { tr. } \\
4.2 \\
2.4 \\
2.2 \\
0\end{array}$ & $\begin{array}{l}14.8 \\
16.3 \\
23.8 \\
29.5 \\
14.9\end{array}$ & $\begin{array}{l}0 \\
3.0 \\
0 \\
1.8 \\
0\end{array}$ & $\begin{array}{l}0 \\
0 \\
0 \\
0 \\
0\end{array}$ & $\begin{array}{l}\text { tr. } \\
0 \\
0 \\
\text { tr. } \\
\text { tr. }\end{array}$ \\
\hline \multicolumn{11}{|l|}{ Hole 380} \\
\hline $\begin{array}{l}1-3,10-20 \\
6-1,93-105 \\
13-1,0-14 \\
27-3,1-13 \\
33-3,95-110\end{array}$ & $\begin{array}{l}14.8 \\
19.7 \\
10.2 \\
14.5 \\
13.4\end{array}$ & $\begin{array}{l}5.9 \\
6.9 \\
5.6 \\
9.6 \\
9.2\end{array}$ & $\begin{array}{l}38.6 \\
39.3 \\
51.1 \\
45.2 \\
53.7\end{array}$ & $\begin{array}{l}7.9 \\
7.2 \\
3.9 \\
7.4 \\
2.1\end{array}$ & $\begin{array}{r}8.9 \\
79 \\
11.7 \\
11.9 \\
9.3\end{array}$ & $\begin{array}{l}0 \\
0 \\
0 \\
2.4 \\
\text { tr. }\end{array}$ & $\begin{array}{r}18.8 \\
9.2 \\
9.7 \\
9.0 \\
4.1\end{array}$ & $\begin{array}{c}5.1 \\
6.6 \\
7.8 \\
0 \\
8.2\end{array}$ & $\begin{array}{l}0 \\
3.2 \\
0 \\
0 \\
0\end{array}$ & $\begin{array}{l}0 \\
0 \\
0 \\
0 \\
0\end{array}$ \\
\hline \multicolumn{11}{|l|}{ Hole $380 \mathrm{~A}$} \\
\hline $\begin{array}{l}5-4,61-74 \\
14-2,62-77 \\
30-2,38-50 \\
62-2,0-15 \\
73-3,16-27\end{array}$ & $\begin{array}{r}16.0 \\
24.4 \\
8.3 \\
11.5 \\
11.4\end{array}$ & $\begin{array}{c}12.9 \\
6.7 \\
0 \\
7.8 \\
14.5\end{array}$ & $\begin{array}{r}41.4 \\
24.0 \\
9.7 \\
28.8 \\
40.5\end{array}$ & $\begin{array}{r}4.6 \\
12.4 \\
14.7 \\
7.9 \\
11.5\end{array}$ & $\begin{array}{r}14.9 \\
9.3 \\
\text { tr. } \\
3.9 \\
4.3\end{array}$ & $\begin{array}{l}0 \\
2.7 \\
\text { tr. } \\
0 \\
6.0\end{array}$ & $\begin{array}{c}7.4 \\
20.5 \\
67.3 \\
0 \\
2.3\end{array}$ & $\begin{array}{c}2.8 \\
0 \\
0 \\
37.1 \\
\text { tr. }\end{array}$ & $\begin{array}{c}0 \\
0 \\
0 \\
2.0 \\
1.7\end{array}$ & $\begin{array}{l}0 \\
0 \\
0 \\
0 \\
7.8\end{array}$ \\
\hline \multicolumn{11}{|l|}{ Site 381} \\
\hline $\begin{array}{l}2-2,124-144 \\
11-2,0-15 \\
19-1,0-15 \\
25-2,40-55 \\
33-4,120-135 \\
37-2,30-40 \\
48-6,110-120\end{array}$ & $\begin{array}{r}17.4 \\
16.9 \\
4.8 \\
16.0 \\
5.4 \\
30.2 \\
6.7\end{array}$ & $\begin{array}{r}7.2 \\
2.1 \\
\text { tr. } \\
4.0 \\
\text { tr. } \\
8.8 \\
20.0\end{array}$ & $\begin{array}{r}38.1 \\
27.9 \\
5.3 \\
19.3 \\
4.7 \\
22.1 \\
30.1\end{array}$ & $\begin{array}{r}9.1 \\
23.6 \\
9.5 \\
32.8 \\
6.3 \\
13.0 \\
12.2\end{array}$ & $\begin{array}{r}11.5 \\
7.8 \\
3.1 \\
19.3 \\
0 \\
5.1 \\
20.8\end{array}$ & $\begin{array}{c}3.9 \\
3.9 \\
0 \\
8.6 \\
0 \\
2.3 \\
7.8\end{array}$ & $\begin{array}{c}4.2 \\
12.7 \\
53.5 \\
0 \\
73.5 \\
\text { tr. } \\
0\end{array}$ & $\begin{array}{c}8.6 \\
5.1 \\
23.8 \\
0 \\
6.7 \\
11.4 \\
0\end{array}$ & $\begin{array}{l}\text { tr. } \\
0 \\
\text { tr. } \\
0 \\
3.4 \\
7.1 \\
\text { tr. }\end{array}$ & $\begin{array}{c}0 \\
0 \\
0 \\
0 \\
0 \\
0 \\
2.4\end{array}$ \\
\hline
\end{tabular}

ranges from 161 to $216 \mathrm{~m} . \mathrm{y}$.; the oldest age is common for the upper part (Würm and Riss-Würm). The Pliocene clays contain terrigenous minerals with an age of 159 to 175 m.y., but fine-silt sediments of the Miocene are 103 to 117 m.y. old. Thus, on the whole, the site shows gradually decreasing age of terrigenous minerals from young deposits to older ones.

The mineral composition of the Pleistocene samples studied varies insignificantly. Only Sample 380-30-2, 38-50 $\mathrm{cm}$ contains authigenic calcite as a major component (Table $3)$. The Miocene deposits are notable for their relative increase of feldspar relative to quartz. If these data are compared with Recent loads from the north (mainly the Danube) and the south (the Sakarya), the mineral composition of Miocene sediments is more similar to the Sakarya sedimentary matter, in which the domination of quartz by feldspar is characteristic. The Danube loads, as is generally known, contain 1.5 to 3 times more quartz than feldspar. One may assume that the delivery of sedimentary material into this area during the Miocene was mainly from the southern part of the drainage area, but later (during Pliocene) the terrigenous material from the northern areas also increased. The increasing role of the Danube loads occurred during the Pleistocene. The age variation of terrigenous minerals in deposits from Holes 380 and 381 , in our opinion, is in accordance with these changes.

In Hole 381 the samples are represented mainly by aleuritic-pelitic and pelitic muds. A portion of them is composed of almost exclusively terrigenous matter $\left(\mathrm{CaCO}_{3}\right.$ $<10 \%$ ), and in only two samples is calcite a predominant mineral (Table 3). The age of terrigenous minerals in Pleistocene sediments is 150 to $180 \mathrm{~m}$.y. These sediments correspond to the lower part of the Pleistocene in Holes 380 and $380 \mathrm{~A}$, where the terrigenous minerals are the same age (about $180 \mathrm{~m} . \mathrm{y}$.). In Pliocene deposits the ages range from 130 to $220 \mathrm{~m}$.y., and the mineral composition there also varies (Table 3). It is interesting that younger age corresponds to terrigenous minerals included with the calcareous sedments (micrite). The formation of calcareous oozes was probably linked to a considerable reduction of the sedimentary material supply into the basin from the drainage area. In the northern parts of the basin as well as in the area of Site 380, the increase in the absolute age values of terrigenous minerals was accompanied by an increase in importance of the terrigenous suspensions, transported from the northern part of the drainage area.

Aleurolites (siltstones) and aleuritic-pelitic muds of the Miocene (Units 9 and 11) consist of the youngest terrigenous minerals ( 80 m.y.B.P.). These data, as those of Site 380 , suggest that sedimentation during the Miocene in this part of the basin was under the prevailing influence of material from the southern drainage area. It is characteristic that here the quartz content decreases sharply, and feldspars occur in greater abundance (Sample 380-48-6, 110-120 cm). The clay mineral ratios are also different (Table 3 ).

\section{SUMMARY}

Variation in the age of terrigenous minerals from Hole 379A sediments indicates that in this part of the basin the supply of sedimentary material during the Pleistocene 
changed repeatedly. The ages obtained, as well as the mineral composition of sediments, indicate that large quantities of sediments were delivered into this area not only from the coast of Turkey, but also from the northern drainage area and from the Caucasus. The increase in the ages of the terrigenous minerals correspond to periods of increasing influence of sedimentary matter from the northern drainage areas. The formation of coarse-grained interbeds of sands and silts and probably most of the turbidites was, however, connected with the accumulation of only the southern sedimentary material.

In the southwestern part of the Black Sea (Holes 380, $380 \mathrm{~A}$, and 381 ), terrigenous sedimentation during the Pleistocene, as well as during the late Neogene, occurred with unequal and changeable supply of sedimentary matter from the surrounding drainage areas. Besides supply of material from the south and the southwest, considerabwe material was supplied from the north (Danube) and also partly from the Russian Platform. The increases in the age of the terrigenous minerals correspond to the periods of the increased removal of material from the northern areas. Judging by these data there was substantial delivery of sedimentary material from the north at some stages of the Pliocene, and it notably increased at the end of the Pleistocene (Riss-Würm and Würm). One can consider in more detail the changes in sources of sedimentary matter supplied given areas (sites) of the Black Sea at different periods by studying the changes in the ages of the terrigenous components, within the limits of precision of the analysis (Table 2).

\section{REFERENCES}

Krylov, A.Ya., and Silin, Yu.I. 1959. Vozmozhnost primeneniya argonovogo metoda opredeleniya vozrasta dlya izucheniya migratzii terrigennykh osadkov (The possible use of argon dating for studies of terrigenous sediment migration): Doklady AN SSSR, v. 129, No. 3.

1963. Primenenie argonovogo metoda opredeleniya vozrasta v morskoy geologii i paleogeografii (The use of argon dating in marine geology and paleogeography). In Khimiya zemnoi kory, v. 1, Izd. AN SSSR.

Krylov, A.Ya., Lisitzin, A.P., and Silin, Yu.I. 1961. Znachenie argonkalievogo otnosheniya $\mathrm{v}$ okeanicheskikh ilakh (The importance of the argon-potassium ratio in oceanic muds): Izv. AN SSSR, Ser. geol., No. 3.

Krylov, A.Ya., Avdzeiko, G.V., Alyapyshev, O.A., Emelyanov, E.M., and Shimkus K.M. 1973. Absolutny vozrast terrigennykh mineralov Chernomorskogo basseina (Absolute age of terrigenous minerals in the Black Sea basin). In Geologoradio-logicheskaya interpretatziya neskhodyashchikhsya znacheniy vozrasta, Izd. "Nauka," Moscow, p. 342-353.

Krylov, A.Ya., Emelyanov, E.M., Silin, Yu.I., Shimkus, K.M., and Tzovbun, Ya. 1973. Nekotorye voprosy formirovaniya terrigennogo materiala glubokovodnykh drevnechernomorskikh i novoevksinskikh osadkov Choernogo morya (Some problems of the terrigenous matter formation in deep-water old Black Sea and Neoeuxinian sediments of the Black Sea). In Geologoradiologicheskaya interpretatziya neskhodyashchikhsya znacheniy vozrasta, Izd. "Nauka," Moscow, p. 330-342. 